\title{
Effect of Heat or Formalin Treatment \\ of Proteinaceous Feed on Protein \\ Degradation with in vitro Rumen \\ Fermentation
}

\author{
Yoichi KoJima and Kanji Okano* \\ Department of Agriculture, Kyoto Prefectural \\ University, Kyoto-shi, 606 \\ * Department of Agriculture, Shiga Prefectural \\ Junior College, Kusatsu-shi 525
}

(Received August 2, 1984)

\begin{abstract}
The effect of heat or formalin treatment of proteinaceous feed on protein degradability in the rumen was studied in two trials, adopting an in vitro culture method. Protein degradation in the rumen was calculated from the measurement of ammonia nitrogen $\left(\mathrm{NH}_{s}-\mathrm{N}\right)$ and bacterial nitrogen. Bacterial nitrogen was estimated from the value of diaminopimelic acid in the medium. Soybean meal (SBM) and casein were treated at $150^{\circ} \mathrm{C}$ for 2 hours (trial 1) or with formalin ( $\mathrm{HCHO}$ ) at $1 \% \mathrm{CP}$ for 72 hours (trial 2). They were incubated in a medium comprising 1 part of rumen liquor and 1 part of McDougald's artificial saliva for 24 hours. The total VFA concentration was higher in untreated substrates. No increase in VFA concentration was observed as the incubation time proceeded in the $\mathrm{HCHO}$ treated casein. $\mathrm{NH}_{3}-\mathrm{N}$ was higher in untreated substrates, especially in untreated casein. There was little change with the time in HCHO treated casein, while a decrease in $\mathrm{NH}_{3}-\mathrm{N}$ was found in $\mathrm{HCHO}$ treated SBM. The protein degradabilities of heat treated SBM, heat treated casein, untreated SBM and untreated casein after 24 hours' incubation in trial 1 were $6.7 \%, 13.3 \%, 34.3 \%$ and $42.3 \%$, respec* tively. Those of $\mathrm{HCHO}$ treated SBM, HCHO treated casein, untreated SBM and un * treated casein in trial 2 were $0.6 \%, 0.0 \%, 32.6 \%$ and $58.0 \%$, respectively.

Jpn. J. Zootech. Sci., 56 (4): 333-340, 1985
\end{abstract}

Ruminants have two kinds of amino acid source from the upper digestive tract, namely dietary protein (bypass protein) and microbial protein, excepting endogenous protein. Obviously, extra energy is necessary to build up microbial protein. How ever, the conversion of dietary poor quality protein to microbial protein in general means improvement of the quality of protein as regards amino acid composition. Meanwhile, it might be better to protect the dietary protein from degradation by microbes in the rumen when the animals are fed a diet containing high quality protein like soybean meal or casein.

Many attempts have been conducted to increase the quantity of protein reaching the lower digestive tracts, by means of protecting dietary protein from degradation in the rumen by physical or chemical procedures ${ }^{1,2,3}$. Such treatment of dietary protein may restrict rumen fermentation and influence the utilization of feed protein. 
No report has documented the state of rumen fermentation to ascertain whether such treatments limit bacterial activity in the rumen or not. Moreover, only ammonia nitrogen $\left(\mathrm{NH}_{3}-\mathrm{N}\right)$ concentration has been measured to discuss the effect of heat treatment or formalin ( $\mathrm{HCHO}$ ) treatment of proteinaceous feed on the protein degradation in some in vitro experiments, ${ }^{4,6}$. In those reports, protein degradation might be underestimated as the result of microbial proliferation.

The present investigation was undertaken to anticipate the effect of heat or $\mathrm{HCHO}$ treatment of proteinaceous feed on rumen fermentation and protein degradation from the value of $\mathrm{NH}_{3}-\mathrm{N}$ and bacterial nitrogen. The bacterial nitrogen was estimated by diaminopimelic acid (DAPA) as the bacterial marker.

\section{Materials and Methods}

Commercial, solvent-extracted soybean meal (SBM) and casein (from milk, Wako Pure Chemical Industries, Ltd., Tokyo) were used as protein source. Corn starch (Wako Pure Chemical Industries, Ltd., Tokyo) was used as carbohydrate source. Heated SBM and casein were prepared by dry-heating for 2 hours in a circulation air oven at $150^{\circ} \mathrm{C}$. The HCHO treatment of both SBM and casein was carried out by adding $1 \mathrm{~g} \mathrm{HCHO}$ to $100 \mathrm{~g}$ crude protein, mixing well, storing in polyvinyl bags for 72 hours and then air-drying until no smell of $\mathrm{HCHO}$ was detected.

Ruminal fluid for incubation was obtained just before the morning feeding from a fistulated steer fed a diet of $15.6 \%$ hay, $38.1 \%$ wheatbran, $20.4 \%$ alfalfa meal, $20.4 \%$ crushed barley, $5.1 \%$ SBM and $0.4 \%$ salt and minerals. The fluid was strained through threefold cheesecloth and then centrifuged at $1000 \mathrm{rpm}$ for 5 minutes. The same quantities of the supernatant solution and McDovgall's artificial saliva ${ }^{7)}$ were mixed and adjusted to $\mathrm{pH} 7.1$ with $\mathrm{Na}_{2} \mathrm{CO}_{3}$. Fifty $\mathrm{ml}$ of this inoculum was added to each of $100 \mathrm{ml}$ glass test tubes containing the appropriate substrate. The tubes were immediately saturated with carbon dioxide, capped with Bunsen valves, and incubated in a water bath at $39.5^{\circ} \mathrm{C}$. Three tubes for each treatment were taken out after 6, 12 and 24 hours' incubation. The $\mathrm{pH}$ values of samples were measured immediately, and stored in a freezer at $-20^{\circ} \mathrm{C}$ until analysis.

In trial 1, the effect of heat treatment was examined using four kinds of substrates, untreated SBM, heated SBM, untreated casein and heated casein. Exactly $50 \mathrm{mg}$ of nitrogen in the form of those nitrogen sources was added to each tube, and $0.5 \mathrm{~g}$ of corn starch was also added as carbohydrate source. Except the control which contained inoculum alone, all tubes contained $100 \mathrm{mg}$ additional nitrogen per $100 \mathrm{ml}$ inoculum, so that degradability (\%) of added protein could be obtained by the sum of $\mathrm{NH}_{3}-\mathrm{N}$ and bacterial $\mathrm{N}$ increase after incubation per $100 \mathrm{~m} l$ culture medium.

Trial 2 was conducted in the same way to examine the effect of HCHO treatment using $\mathrm{HCHO}$ treated SBM and casein instead of heated substrates in trial 1.

Total VFA concentration was determined by PACKETT and McCunE's method ${ }^{8}$. $\mathrm{NH}_{3}-\mathrm{N}$ concentration was determined by the phenol-hypochloride reaction ${ }^{9}$. DAPA as the marker for bacterial protein in the samples after 24 hours' incubation was 
determined by the method of ion exchange chromatography using an automatic amino acid analyzer (Model KLA-5, Hitachi Co. Ltd., Tokyo). Bacterial N was calculated by the equation $\mathrm{N}=\mathrm{DAPA} \times 18$ of Hutron et $a l^{(0)}$.

\section{Results}

The effects of heat treatment on the periodical changes of average $\mathrm{pH}$, VFA concentration and $\mathrm{NH}_{3}-\mathrm{N}$ concentration are shown in Figure 1. DAPA concentration and increments of $\mathrm{NH}_{3}-\mathrm{N}$ and bacterial $\mathrm{N}$ in the culture medium after 24 hours' in. cubation and the estimated degradability (\%) of added protein are shown in Table 1.

VFA concentration was increased by $\mathrm{N}$ substrate addition, the increase being most remarkable in untreated SBM. VFA production in the tubes containing heated SBM or heated casein was restricted compared with untreated ones. An inverse relationship between VFA concentration and the ruminal $\mathrm{pH}$ is apparent. The $\mathrm{NH}_{9}-\mathrm{N}$ concentration increased in untreated protein substrates, most remarkably in the untreated casein. The $\mathrm{NH}_{3}-\mathrm{N}$ concentration was depressed by heat treatment in SBM. The DAPA concentration after 24 hours' incubation was greater in amount with untreated protein substrates than with heat treated substrates. This was especially great in the SBM.

The effects of $\mathrm{HCHO}$ treatment on the $\mathrm{pH}$ and chemical values are shown in

Table 1. Effects of heat treatment on DAPA concentration and nitrogen status with in vitro rumen fermentation ( 24 hrs)

\begin{tabular}{lcccc}
\hline & $\begin{array}{c}\text { DAPA }^{3} \\
\text { concentration } \\
(\mathrm{mg} / \mathrm{d} l)\end{array}$ & $\begin{array}{c}\text { Increased } \\
\mathrm{NH}_{3}-\mathrm{N}(\mathrm{mg} / \mathrm{d} l)\end{array}$ & $\begin{array}{c}\text { Nitrogen status } \\
\text { bacterial } \mathrm{N} \\
(\mathrm{mg} / \mathrm{d} l)\end{array}$ & $\begin{array}{c}\text { Degradation } \\
\text { of protein }(\%)\end{array}$ \\
\hline Untreaed SBM & 1.73 & 10.2 & 24.1 & 34.3 \\
Heated SBM & 1.05 & -5.1 & 11.8 & 6.7 \\
Untreated casein & 1.14 & 28.8 & 13.5 & 42.3 \\
Heated casein & 0.99 & 2.6 & 10.7 & 13.3 \\
\hline
\end{tabular}

a DAPA concentration was $0.39 \mathrm{mg} / \mathrm{dl}$ at 0 hour.

Table 2. Effects of HCHO treatment on DAPA concentration and nitrogen status witn in vitro rumen fermentation ( $24 \mathrm{hrs}$ )

\begin{tabular}{lcccc}
\hline \hline & $\begin{array}{c}\text { DAPA } \\
\text { concentration } \\
(\mathrm{mg} / \mathrm{d} l)\end{array}$ & $\begin{array}{c}\text { Increased } \\
\mathrm{NH}_{3}-\mathrm{N}(\mathrm{mg} / \mathrm{d} l)\end{array}$ & $\begin{array}{c}\text { Nitrogen status } \\
\text { Increased } \\
\text { bacterial } \mathrm{N} \\
(\mathrm{mg} / \mathrm{d} l)\end{array}$ & $\begin{array}{c}\text { Degradation } \\
\text { of protein }(\%)\end{array}$ \\
\hline Untreated SBM & 1.48 & 13.9 & 18.7 & 32.6 \\
HCHO treated SBM & 0.89 & -7.4 & 8.0 & 0.6 \\
Untreated casein & 1.18 & 44.8 & 13.2 & 58.0 \\
HCHO treated casein & 0.45 & -0.2 & 0.1 & 0.0
\end{tabular}

a DAPA concentration was $0.44 \mathrm{mg} / \mathrm{d} l$ at 0 hour. 
KoJima and OKano
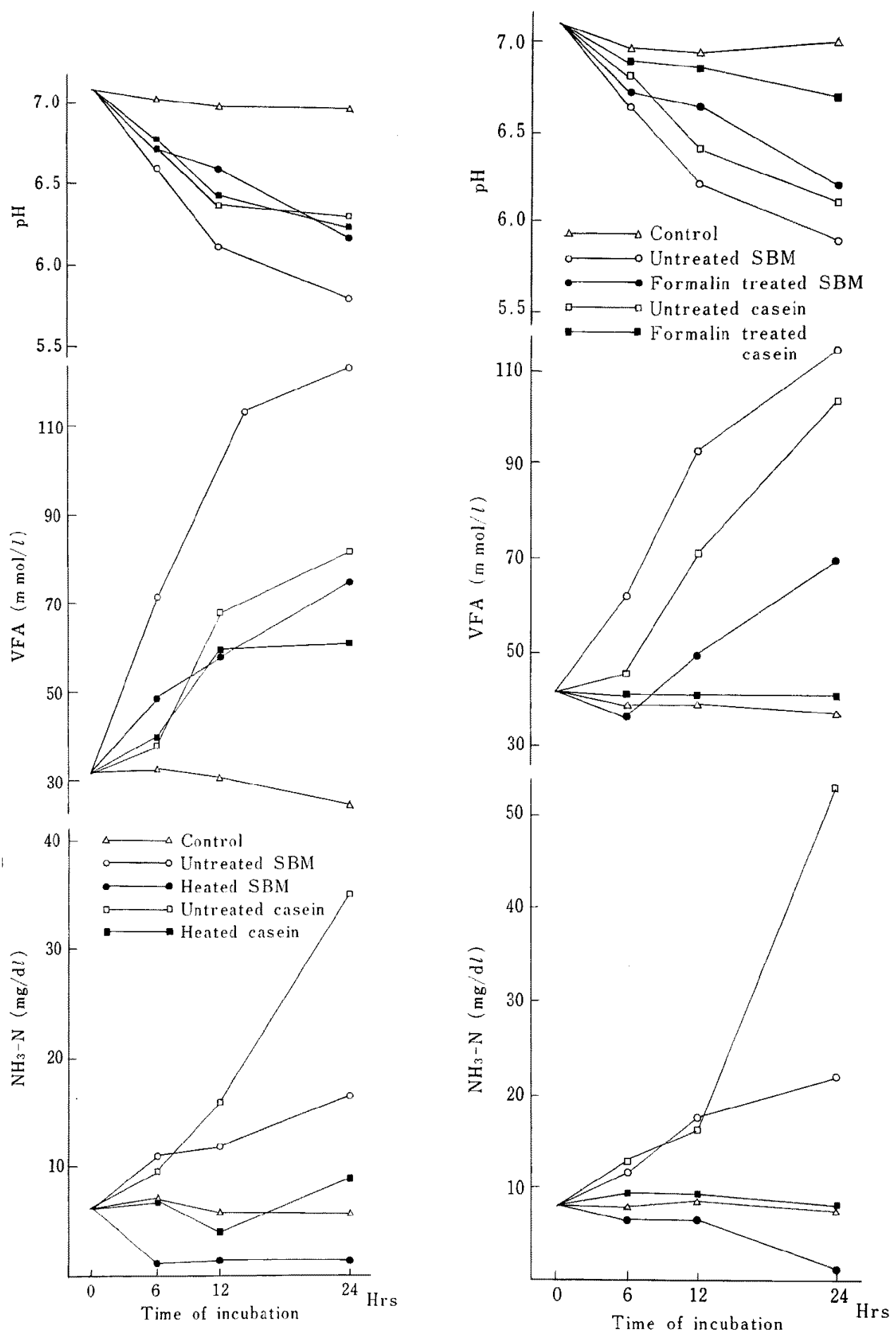

Fig. 1. Effects of heat treatment of protein source on $\mathrm{pH}, \mathrm{VFA}$ and $\mathrm{NH}_{3}-\mathrm{N}$ concentration in in vitro rumen fermentation.

Fig. 2. Effects of formalin treatment of pro* tein source on $\mathrm{pH}$, VFA and $\mathrm{NH}_{3}-\mathrm{N}$ concentration in in vitro rumenfermentation. 
Figure 2. DAPA concentration and the nitrogen status after 24 hours' incubation are shown in Table 2.

The $\mathrm{pH}$ values began to decline after the start of incubation in each substrate. This tendency was more pronounced in SBM than in casein. It was observed that $\mathrm{HCHO}$ treatment of each protein source apparently kept $\mathrm{pH}$ values higher than in untreated substrate. The VFA concentration increased rapidly after the start of incubation in untreated SBM and untreated casein. The tubes which contained the HCHO treated substrates showed lower VFA levels than the untreated substrates; no increase of VFA was observed in $\mathrm{HCHO}$ treated casein.

\section{Discussion}

Heat or HCHO treatment obviously depressed the production of VFA and $\mathrm{NH}_{3}-\mathrm{N}$, regardless of source of protein. However, an appreciable change can be seen in VFA and $\mathrm{NH}_{3}-\mathrm{N}$ concentration for heat treated SBM, heat treated casein and HCHO treated SBM. Also, there was no increase in VFA and $\mathrm{NH}_{3}-\mathrm{N}$ concentration in the control. It is considered that added starch and protein, and carbohydrates contained in SBM seem to be the most probable sources for VFA production. The increases in both VFA and $\mathrm{NH}_{3}-\mathrm{N}$ concentration in untreated SBM show that all of these three were principal sources for VFA production. However, in the case of heat treated SBM, the VFA concentration increased, but the values were not higher than those for untreated SBM; and the $\mathrm{NH}_{3}-\mathrm{N}$ concentration showed a lower value in heat treated SBM. These suggest that the protein in SBM which was one of the sources of VFA production was limited by heat treatment. And it could be assumed that the principal sources for VFA production were the starch and the carbohydrate in SBM. It is well known that lysine rich in SBM interacts with glucose by heat treatment and they make a compound which is not easily attacked by enzymatic digestion. This suggests that the heat treatment of SBM might affect not only the degradation of protein but the availability of carbohydrate by enzyme. Therefore, it might be expected that the principal source for VFA production was only starch in the case of heat treated SBM, and it induced the lower VFA production than the untreated SBM.

On the other hand, it is considered that the depression of VFA production would also occur in cases where nitrogen sources for microbial proliferation were limited. The $\mathrm{NH}_{3}-\mathrm{N}$ concentration at 6 hours showed no increase in heat and $\mathrm{HCHO}$ treated casein, and even a decrease in both treatments of SBM. At the start of incubation, the $\mathrm{NH}_{3}-\mathrm{N}$ concentration was approximately $6 \mathrm{mg} / \mathrm{d} l$ in trial 1 and approximately 8 $\mathrm{mg} / \mathrm{d} l$ in trial 2. These values are sufficient for microbial proliferation"1). Therefore, the lower value of VFA production in heat treated SBM at the early stage of incubation might be attributed exclusively to the depressed supply of easily available carbohydrate and protein from heat treated SBM. More frequent measurements at the early stage of incubation are necessary to make this point clear.

There are some reports on the effect of heat or HCHO treatent. CHALMERs et al. ${ }^{12)}$ reported that the feeding of heated casein reduced rumen $\mathrm{NH}_{8}-\mathrm{N}$ concentra- 
tion. A similar result with heated SBM was also reported by Hubson et al. ${ }^{13)}$ THomas et al..$^{5)}$ reported that the denaturation by heat treatment at $138^{\circ}$ or $149^{\circ} \mathrm{C}$ for 4 hours protected the SBM from degradation by rumen microbes. On the other hand, SHARMA et al. ${ }^{2)}$ reported that $0.7 \mathrm{~g}$ HCHO per $100 \mathrm{~g} \mathrm{CP}$ was necessary to reduce the degradation of casein by rumen microbes. Schmid et $a l .{ }^{14}$ ) and Thomas et $a{ }^{\left({ }^{5}\right)}$ reported that more than $0.4 \mathrm{~g} \mathrm{HCHO}$ per $100 \mathrm{~g} \mathrm{CP}$ was necessary to inhibit the release of $\mathrm{NH}_{9}-\mathrm{N}$ from degradation of SBM protein with in vitro rumen fermentation. In the present experiment, higher temperatures of more HCHO than in those experiments were adopted for protein denaturation. Therefore, the results obtained were clearly in the same direction.

Fairly high VFA production could be seen in heated SBM and casein, and a considerable decrease and transitory decrease in $\mathrm{NH}_{3}-\mathrm{N}$ in heated casein and SBM respectively occurred at the same time. This would indicate that the VFA production in heated SBM and casein was not so remarkable as compared with in untreated ones, however the considerably active proliferation was carried out in the case of heated SBM and casein. On the other hand, there was no apparent increase of VFA production and $\mathrm{NH}_{3}-\mathrm{N}$ at any time of incubation in $\mathrm{HCHO}$ treated casein nor in the control. But a fairly large increase in VFA production and decrease in $\mathrm{NH}_{3}-\mathrm{N}$ could be found in $\mathrm{HCHO}$ treated SBM. The difference in results between SBM and casein in $\mathrm{HCHO}$ treatment would be considered to be owing to the difference in sensitivity to $\mathrm{HCHO}$. It can be assumed that the $\mathrm{HCHO}$ treated casein obtained almost perfect resistivity to degradation by rumen microbes.

The above mentioned presumptions would be supported also by the results of increased $\mathrm{NH}_{3}-\mathrm{N}$, increased bacterial $\mathrm{N}$ and the degradability of protein after 24 hours' incubation. In other words, in the case of heat treatment, the amount of increased bacterial $\mathrm{N}$ was lower than untreated ones and these values were closely related to the VFA levels at 24 hours. This clearly indicated that microbial proliferation was closely associated to VFA production. The reduction in $\mathrm{NH}_{3}-\mathrm{N}$ and lower value for increased bacterial $\mathrm{N}$ in the heated SBM might show that the deficiency of an easily available $\mathrm{N}$ source through heat treatment would restrict microbial proliferation and result in lower levels of VFA production. The same pattern can be seen in the case of $\mathrm{HCHO}$ treatment.

In the case of untreated casein both in trial 1 (heat treatment) and trial 2 i $\mathrm{HCHO}$ treatment), the degradability of protein was high, especially the value for the untreated casein which was the control in trial 2, at 58.0\%. However, this value was obviously lower than the degradability of casein $\mathrm{N}$ in actual feeding. Part of the explanation for the unexpected value may lie in the difference between the actual $\mathrm{N}$ content of bacteria and the $N$ content calculated from the equaton of HuTton et al. ${ }^{10}$ ) and/or in the difference in the ratio of the amount of nitrogen source to bacterial population between in vitro experiment and in actual feeding. It is considered that the equation to calculate bacterial $\mathrm{N}$ from DAPA should be obtained in every experiment, and that the addition of smaller amounts of protein $\mathrm{N}$ than $100 \mathrm{mg} / \mathrm{d} \mathrm{l}$ might be 
desirable to obtain high protein degradability with in vitro experiments. In the case of untreated SBM as control for the heated SBM and HCHO treated SBM, 10. 2 (trial 1) and $13.9 \mathrm{mg} / \mathrm{d} l$ (trial 2) of $\mathrm{NH}_{3}-\mathrm{N}$ were increased in the medium after 24 hours. In the case of untreated casein, 28.8 and $44.8 \mathrm{mg} / \mathrm{d} l$ of $\mathrm{NH}_{3}-\mathrm{N}$ were accumulated in 24 hours' incubation. If $\mathrm{NH}_{3}-\mathrm{N}$ arising from added protein was absorbed via rumen wall and excreted as urea into the urine, there must be resigned the considerable amount of high quality amino acid source.

It can be recognized that heat or HCHO treated casein and SBM became resistant to attack by rumen microbes. In actual feeding, if these proteins escaped into the post reticulo-rumen without being degraded, it would induce a shortage of readily available nitrogen for microbial proliferation in the rumen. In that case, it would be necessary to satisfy the nitrogen requirement of rumen microbes with some methods. Urea- $\mathrm{N}$ added to the diet as a vicarious nitrogen source might assume a great role when protein protected by some treatment from microbial attack in rumen was given as feed. WALLER et al. ${ }^{15)}$ reported that better nitrogen utilization would be found with a diet containing distillers' byproducts, which degrade with difficulty, when urea was added to the diet as a vicarious nitrogen source. What happens to vicarious nitrogen sources in the digestive tract of ruminants must be studied, and thereby, information about how to use it in actual feeding for maximum production must be obtained.

It is not clear in the present study whether the treated protein escaping into the post reticulo-rumen is attacked readily by the animal's own enzyme. Further study would be necessary to clarify these points.

\section{References}

1) Nishimuta, J. F., D. G. Ely and J. A. Boling, J. Anim. Sci., 39: 952-957. 1974.

2) Sharma, H. R., J. R. Ingalls and R. J. Parker, Can. J. Anim. Sci, 54: 305-313. 1974.

3) Amos, H. E. and J. Evans, J. Anim. Sci., 43: 861-868. 1976.

4) Dinius, D. A., C. M. LYon and H. M. Walker, Jr., J. Anim. Sci., 38: 467-474. 1974.

5) Thomas, E., A. Trenkle and W. Burroughs, J. Anim. Sci., 49: 1337-1345. 1979.

6) Phillips, W. A., J. Anim. Sci., 53: 1616-1622. 1981.

7) McDougall, E. J., Biochem. J., 43: 99-109. 1948.

8) Packett, L. W. and R. W. McCune, Appl. Microbiol., 13: 22-27. 1965.

9) Oruda, H. and S. Fujn, The Saishin-Igaku, 21: 622-627. 1966.

10) Hutton, K., F. J. Bailey and E. F. Annison, Br. J. Nutr., 25: 165-173. 1971.

11) Satter, L. D. and L. L. Slyter, Br. J. Nutr., 32: 199-208. 1974.

12) Chalmers, M. I., D. P. Cuthbertson and R. L. M. Synge, J. Agric Sci., 44: 254-262. 1954.

13) Hudson, L. W., H. A. Glimp, C. O. Little and P. G. Woolfolk, J. Anim. Sci., 28: 279282. 1969.

14) Schmidt, S. P., N. J. Benevenga and N. A. Jorgensen, J. Anim. Sci., 37: 1238-1245. 1973.

15) Waller, J., T. Klopfensteia and M. Poos, J. Anim. Sci., 51: 1154-1167, 1980. 


\title{
蛋白質䣳料の加熱処理またはホルマリン処理が，反すう 胃微生物による in vitro での蛋白質分解に及ぼす影響
}

\author{
小島洋一・岡野寬治* \\ 京都府立大学農学部，京都市 606 \\ * 滋賀県立短期大学農業部，草津市 525
}

バイパス蛋白質を增加させる手段として，蛋白質餇料 に加熱妈理亡たはホルマリン妈理を行なった場合の，反 寸ら胃内発醉扰よび細菌態䖵白望量の变化について予備 的な知見を得るために 2 回の in vitro 発醳試験を行なっ た. 試験 1 では通風乾燥器内で $150^{\circ} \mathrm{C} 2$ 特間の加熱观理 をした大豆粕掞よびカゼインをまた，陚験 2 では CP の $1 \%$ に相当するホルマリンで 72 時間処理をした大豆 粕就よびカゼインを，牛第一罢液を1に対して McDou一 GALL人工睡液を 1 混合した培着液にて 24 時間培圽し， それぞれ無処理の場合と比軦した。

VFA 濃度は大豆粕, カゼインともに無処理で高くなっ た. ホルマリン処理カゼインでは時間の経過にともなら VFA 濃度の增加が認められなかった。フンモ二ア態窒 素濃度は無処理区で高く,とくに24 時間後の無処理カゼ
インが著しく高かったが，ホルマリン処理カゼインでは 時間の経過に上る变化はによどるれず，ホルマリン 処理大豆粕では時間の経過とともに低くなった。

ジアミノピメリン酸を指標物䡠として用い, 細菌態N 量を算出し，その值と $\mathrm{NH}_{3}-\mathrm{N}$ 量加ら 24 時間培荺後の 蛋白態Nの分解率（\%)を求めた結果, 試験 1 では加熱 起理大豆粕，無処理大豆粕，加熱処理カセインン特よ゙然 処理カゼインでは，をれそれ 6.7，34.3，13.3抢よび

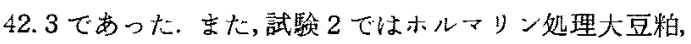
無処理大豆粕，ホルマリン処理力ゼイン尔よび無処理力 ゼイの分解率は，それぞれ，0.6，32.6，0.0括よび 58.0であった。

日畜会報，56(4)：333-340，1985 